\title{
Aedes aegypti, Aedes albopictus, and dengue in Argentina: current knowledge and future directions
}

\author{
Darío Vezzani ${ }^{+}$, Aníbal E Carbajo \\ Unidad de Ecología de Reservorios y Vectores de Parásitos, Departamento de Ecología, Genética y Evolución, Facultad de Ciencias \\ Exactas y Naturales, Universidad de Buenos Aires, Ciudad Universitaria, Pabellón II, 4o piso, C1428EHA Buenos Aires, Argentina
}

Since the reinfestation of South American countries by Ae. aegypti, dengue fever (DF) and dengue hemorrhagic fever (DHF) have become a major public health concern. The aim of this paper was to review the information related with Aedes vectors and dengue in Argentina since the reintroduction of Ae. aegypti in 1986. The geographic distribution of Ae. albopictus is restricted to the Northeast, and that of Ae. aegypti has expanded towards the South and the West in comparison with the records during the eradication campaign in the 1960s. Since 1998, 4,718 DF cases have been reported concentrated in the provinces of Salta, Formosa, Misiones, Jujuy and Corrientes. Despite the circulation of three dengue virus serotypes (DENV-1, -2 and -3) in the North of the country, DHF has not occurred until the present. The information published over the last two decades regarding mosquito abundance, temporal variations, habitat characteristics, competition, and chemical and biological control, was reviewed. Considering the available information, issues pending in Argentina are discussed. The presence of three DENV, the potential spread of Ae. albopictus, and the predicted climate change suggest that dengue situation will get worse in the region. Research efforts should be increased in the Northern provinces, where DHF is currently an actual risk.

Key words: Aedes aegypti - Aedes albopictus - dengue - yellow fever - mosquito ecology - vector control

Aedes aegypti and Aedes albopictus are invasive species that are currently widespread throughout tropical to temperate regions of the globe. Their ability to breed in artificial containers facilitated their passive spread in the last decades through main transportation routes (Lounibos 2002). These mosquito species coexist in man-made containers in urban, suburban and rural settlements in tropical and subtropical regions (Passos et al. 2003, Juliano et al. 2004, Honório et al. 2006). In addition, Ae. albopictus immatures inhabit natural containers as bromeliads, bamboo stumps and tree-holes (Hawley 1988, Marques et al. 2001). The relationships between both Aedes species have fascinated mosquito researchers during the last decades due to their competition interactions observed for example in the USA and Brazil, which suggested a competitive advantage for Ae. albopictus over Ae. aegypti (O'Meara et al. 1995, Juliano 1998, Lounibos 2002, Braks et al. 2004, Juliano et al. 2004). Besides this ecological interest, the actual consequence of the potential displacement of Ae. aegypti by Ae. albopictus in terms of diseases transmission remains unknown in many regions.

Ecological and behavioral knowledge about mosquito populations are required as a baseline to understand the transmission dynamics of vector-borne pathogens and therefore to implement effective control programs. In the last decades, the knowledge about ecology, diseases transmission and control of Ae. albopictus and Ae. aegypti has increased worldwide. The objectives of this

\footnotetext{
+Corresponding author: vezzani@ege.fcen.uba.ar Financial support: CONICET

Received 29 August 2007

Accepted 8 January 2008
}

study were to review the information related with both vectors and dengue in Argentina since the reintroduction of Ae. aegypti in 1986 and to discuss future directions in research and control of dengue vector in the country.

Ae. aegypti reinfestation and Ae. albopictus infestation: short overview

In Argentina, Ae. aegypti was present during the first half of the past century in the Northern and Central provinces: Jujuy (JU), Salta (SA), Formosa (FO), Misiones (MI), Corrientes (CR), Chaco (CH), Santiago del Estero, Tucumán, Catamarca (CA), La Rioja, Santa Fe, Entre Ríos (ER), Córdoba (CO) and Buenos Aires (BA) (Bejarano 1979) (Figure). A hemispheric eradication campaign began in 1947 with the aim to eliminate Ae. aegypti from the continent (PAHO 1994). In Argentina, it was considered eradicated in 1963 by the National Public Health Ministry (NPHM) (Carcavallo \& Martínez 1968), and in 1965 by the Directing Council of the Pan American Health Organization (Bejarano 1979).

Since the vector reintroduction in Brazil in 1975 (Schatzmayr 2000), all the Southern Cone countries have been reinfested. The last countries in which reinfestation was detected were Uruguay in 1997 (Salvatella 1997) and Chile (Eastern Island) in 2000 (MSC 2007). In Argentina, Ae. aegypti reinfestation was detected in 1986 in MI (Posadas and Puerto Iguazú) and FO (Clorinda and Puerto Pilcomayo) (Curto et al. 2002). A few years later, it was recorded a thousand kilometers to the South in BA (Campos 1993). In 1995 it was confirmed in the centre of the country (CO) (Avilés et al. 1997) and in Buenos Aires city (Junín et al. 1995). The distribution of the vector between 1991 and 1999 was exhaustively studied and mapped at the locality level throughout the country (Curto et al. 2002). Currently, the westernmost find- 


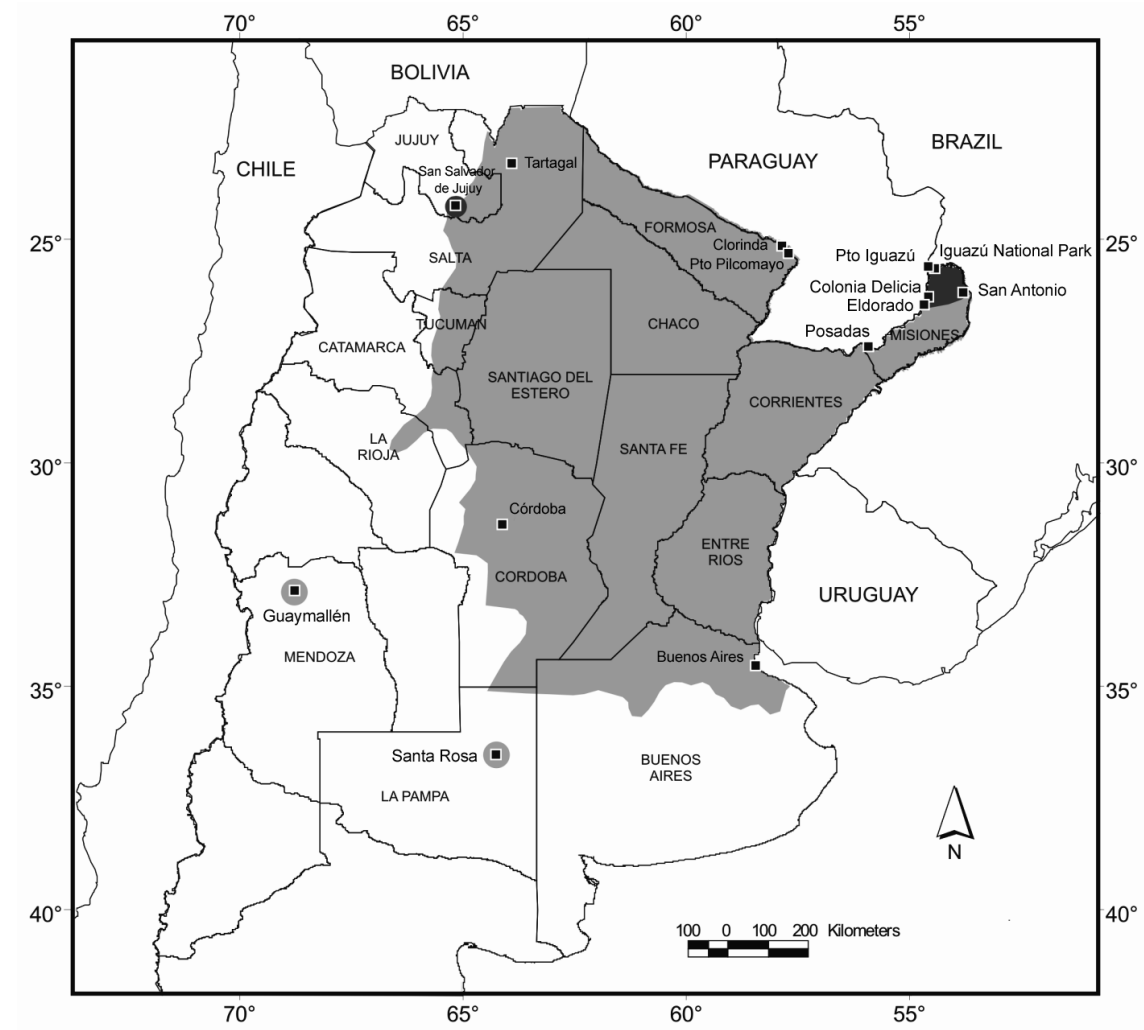

Current geographic distribution of Aedes aegypti (light grey) and Aedes albopictus (dark grey), and geographic locations of Argentinean provinces (uppercase) and localities (lowercase) mentioned in the text.

ing corresponds to the province of Mendoza in the year 2000 (Department of Guaymallén) (Domínguez \& Lagos 2001) and the southernmost record is in the province of La Pampa (Santa Rosa) (Rossi et al. 2006) (Figure). This implies that the distribution has expanded towards the West and South in comparison to the historical distribution. Argentinean Ae. aegypti subpopulations showed high levels of genetic polymorphism which suggest different origins from genetically different subpopulations (de Sousa et al. 2000). Moreover, vector populations of the two major cities of the country, Córdoba and Buenos Aires, have probably been introduced through the main commercial routes from Bolivia and Brazil, respectively (de Sousa et al. 2001).

Ae. albopictus has a short history in America and particularly in Argentina. Initial discovery of this species in continental North America was in 1985 in Texas (USA) and four years later it was widely distributed across 18 states, whereas in South America it was found in Brazil during 1986 (Rai 1991). In Argentina it was detected for the first time in early 1998 in two Northeast localities of MI, close to the Brazilian border (Rossi et al. 1999, Schweigmann et al. 2004). A few years later it was recorded in other two places of MI (Rossi et al. 2006). In the Northwester province of JU there is only one record of two adults found near the airport of San Salvador de Jujuy city in 1998, but further inspections did not detect the mosquito (C Ripoll, unpublished observations). To our knowledge, there is no other record of Ae. albopictus in Argentina, however in 2003 it was found in Uruguay (Rossi \& Martínez 2003, Salvatella \& Rosa 2003) at a higher latitude than the Argentinean records, suggesting a current spreading to coldest areas in South America.

\section{Dengue and yellow fever}

The reintroduction of Ae. aegypti in America in the last decades and the expansion towards the South of dengue virus (DENV) transmission increases the risk for dengue infection in Argentina (Avilés et al. 1999). In neighboring countries, the first dengue outbreaks occurred in Brazil in 1982 and 1986 (Schatzmayr et al. 1986, PAHO 1994), Bolivia in 1987-1988 (Gianella et al. 1998) and Paraguay in 1988-1989 (PAHO 1994). Chile suffered two outbreaks in Easter Island, in 2002 and 2007, but the continental land remains free of autochthonous cases (MSC 2007). Uruguay is the only country in the region where autochthonous cases were not confirmed until the present. Because of the upward trend in dengue incidence in America, in 1999 the WHO (2000) recommended a new global strategy for prevention and control of dengue fever (DF) and dengue hemorrhagic fever (DHF). In 2003, the resolution CD44.R9 was approved by the 44th Directing Council of the Pan American Health Organization with the goal to promote changes in national programs policies and introduce a model of integrated strategy for dengue prevention and control (EGI-dengue) in the region of the Americas. Until middle 2007, 11 countries in the region have developed or implemented a national 
strategy and in Argentina EGI-dengue is currently under development (San Martín \& Brathawaite-Dick 2007).

After the vector reintroduction in Argentina, the first isolated dengue cases were detected during 1997 in SA (Avilés et al. 1999), and these records were the first since the 1916 epidemic occurred in ER (Gaudino 1916). In 1998 an epidemic was recorded in SA and two years later in MI and FO (BEN 2001). Posterior laboratory studies confirmed 696 indigenous cases of DF as a result of these outbreaks (Avilés et al. 2003b). Serologic surveys conducted in the Northeast showed low seroprevalences in MI (1\%), CR (2.3\%), CH (5.5\%), and FO (0\%) (Gorodner et al. 2000). Since 1998 to middle of 2007, a total of 4,718 DF cases were reported (PAHO 2007) and the majority concentrated in SA, FO and MI (BEN 2001, 2003). A recent work studied a 109-day outbreak in Tartagal (SA) involving 487 DF suspected cases; spatio-temporal clustering of the cases was found and dengue transmission risk was estimated by associating the cases to thematic maps built with satellite images (Rotela et al. 2007). To date, DF outbreaks have occurred only in FO, MI, SA, JU and CR. These hot spots, matched with the higher risk areas suggested by the theoretical dengue transmission risk maps of Argentina performed by Carbajo et al. (2001). In addition, dozens of imported cases had been frequently detected in Buenos Aires city and its outskirts (e.g., Seijo et al. 2000). Regarding DENV serotypes, DENV-1 and DENV-2 were responsible for autochthonous virus transmission between 1997 and 2001 (Avilés et al. 2003b) and DENV-3 was first registered in 2003 co-circulating with DENV-1 and DENV-2 (BEN 2003). Only strains of DENV-1 have been sequenced (Avilés et al. 2003a, Barrero \& Mistchenko 2004). DHF was not detected until the present despite the circulation of three serotypes in the North of the country.

Yellow fever (YF) transmitted by Haemagogus spp. has been periodically reported in wild areas from neighboring countries. Bolivia and Brazil informed 234 cases during the period 1998-1999 (WER 2000), 15 in 2004 (WER 2005) and 19 in 2005 (WER 2006). The reinfestation by Ae. aegypti and the introduction of Ae. albopictus increase the risk of future re-emergence of urban YF (Monath 2001). This form of the disease had not been reported in the Americas since 1954, but the six cases detected in Santa Cruz city (Bolivia) in 1997-1998 strongly suggested that the urbanization of YF in the continent is not hypothetical and that urgent intervention is needed (Van der Stuyft et al. 1999). In Argentina, the last outbreak of YF was sylvatic and occurred in the Northeastern provinces of MI and CR during 1966 (Bejarano 1979). In 2001, an YF epizootic outbreak in monkeys occurred in Brazil close to the Argentinean border and the NPHM carried out a preventive plan to reduce transmission risk in some localities of MI and CR (Pedroni 2001). The main actions were YF vaccination of the population at risk, reduction of Ae. aegypti populations and surveillance of virus circulation in mosquitoes and monkeys; no human case was detected.

To the present, Ae. albopictus has not been incriminated as a vector of any disease in the country.

\section{Aedes spp. in Argentina: state of art}

Mosquito abundance - Ae. aegypti abundance was estimated in localities of five provinces through traditional indices: house index (HI), container index (CI) and Breteau index (BI) (PAHO 1994). Among the areas in which dengue outbreaks took place, Clorinda (FO) showed $\mathrm{HI}$ and $\mathrm{BI}$ of $39 \%$ and 87 during 2002 (Masuh et al. 2003a), and Colonia Delicia (MI) 51\% and 106, respectively, during 2000 (Masuh et al. 2003b). These indices were also estimated in areas in which DENV transmission was not demonstrated until the present. In two localities of $\mathrm{CH}$ the $\mathrm{HI}$ reached up to $70 \%$, CI up to $39 \%$ and BI $>200$ (Stein \& Oria 2002), and in Córdoba city the infestation values were $\mathrm{HI}=47 \%, \mathrm{CI}=24 \%$ and $\mathrm{BI}=$ 106 (Almirón \& Asis 2003). In Buenos Aires city and its outskirts, traditional indices evaluated in premises ranged as follows: $\mathrm{HI}=8-37 \%, \mathrm{CI}=2.4-12.3 \%$ and $\mathrm{BI}=10.8$ 58.7 (Schweigmann et al. 1997, 2002), and the highest CI recorded was 39\% in a cemetery during March (Vezzani et al. 2004a). All these studies showed Ae. aegypti infestation levels higher than those traditionally considered as thresholds for DENV transmission. However, some of the highest values could be overestimated due to the low number of premises inspected (e.g., BI $>200$, sample size $<50$ premises).

Temporal variations - Seasonal oviposition activity and abundance patterns of the vector are necessary to estimate the timing for virus transmission risk. In this sense, studies performed in different regions of the country showed different seasonal patterns. In the Northwest (SA), Ae. aegypti oviposition activity was detected during the whole year with a peak in March associated with rainfall (Micieli \& Campos 2003). In all the other studied areas $(\mathrm{CH}, \mathrm{CO}$ and $\mathrm{BA})$ oviposition activity and immature abundance were not detected during winter. In general, oviposition activity was recorded since OctoberNovember until May-June strongly associated with temperature and/or precipitation variations, but the peaks were recorded in different months in the three provinces (Campos \& Maciá 1996, Almirón \& Ludueña Almeida 1998, Domínguez et al. 2000, García et al. 2002, Carbajo et al. 2004, Vezzani et al. 2004a, Stein et al. 2005, Micieli et al. 2006). In CH, the maximum egg and immature abundances were found in November-December, in $\mathrm{CO}$ in December-January, and in BA in February-March. These differences are probably the consequence of rainfall and temperature dynamics across the latitudinal gradient. Egg and larva development times increased as temperature dropped, varying between 3.18 and 4.43 days and 8.91 and 20.82 days, respectively, for Ae. aegypti strain from Córdoba city (Domínguez et al. 2000). A stochastic population dynamics model applied for Buenos Aires city suggested that the persistence of Ae. aegypti local population depends on the average yearly temperature, seasonal temperature variation and number of breeding sites (Otero et al. 2006). Inter-annual variation of $A e$. aegypti abundance was related with atmospheric conditions caused by El Niño and La Niña events in some localities (de Garín et al. 2002, Micieli et al. 2006). A theoretical assessment about the effects of temperature and humid- 
ity saturation deficit over vector survival and gonotrophic cycles in Buenos Aires city showed that historical vector detection matched with periods of favorable conditions (de Garín et al. 2000). Bejarán et al. (2000) performed a similar approach for the whole country and included dengue virus development. The latter two studies suggested an increasing trend in the favorability of meteorological conditions for Ae. aegypti during the second half of the last century and considered this trend a consequence of climatic variability.

Habitat characteristics - Ae. aegypti habitat suitability was assessed at different spatial scales; i.e. within a city, among microenvironments and in regard to types of container used as breeding sites. Ovitrap surveys conducted throughout Buenos Aires city suggested that downtown neighborhoods close to the river have lower levels of infestation than the rest of the city (Schweigmann et al. 2002, Carbajo et al. 2004). A posterior study involving spatial analysis found strong evidence that in Buenos Aires city mosquito proliferation is highest in medium urbanization levels and minimum in densely built areas (Carbajo et al. 2006). In this study, the variables positively related to oviposition activity were house density and proximity to industries, flat density was negatively associated, and vegetation cover was between the variables not significantly associated. At a more detailed scale, among cemeteries within the same city, vegetation cover was strongly correlated with Ae. aegypti infestation (Vezzani et al. 2001) and at a microhabitat scale the presence of immatures was enhanced in sites less exposed to sunlight, with taller and closer vegetation, and with shaded and vegetated surroundings (Vezzani et al. 2005). On the contrary, Almirón et al. (1999) found no difference in the number of eggs collected in ovitraps located under different conditions of light exposition in one premise of Córdoba city. Field experiments suggested that oviposition response depends stronger on container color than on water surface area, and the response to color would depend on the microenvironment lighting condition (Badano \& Regidor 2002). Several field studies identified Ae. aegypti habitat types (Schweigmann et al. 1997, Borda et al. 1999, Stein et al. 2002, Stein \& Oria 2002, Zapata et al. 2002, Almirón \& Asis 2003) but in general gave no information about availability of each container type or productivity, hampering key containers identification (i.e., those of higher productivity). Key containers identified for Ae. aegypti control were tires and wide mouth containers in CH (Stein et al. 2002, Stein \& Oria 2002). Studies restricted to cemeteries recorded mosquito immatures in flower vases made of plastic, metal, ceramic and glass (García et al. 2002) and the use of each type of container varied according to sun exposure; in shaded areas it was proportional to the availability, and in sun exposed areas plastic and metal containers were the most and less frequent habitats, respectively (Vezzani \& Schweigmann 2002). Also in cemeteries, Vezzani et al. (2004b) reported that Ae. aegypti productivity was higher in containers of 1-5 1 than in those up to 11 .

Competition - Information about inter- and intraspecific competition involving mosquitoes is certainly scarce in Argentina. Some studies reported the coexistence frequency of Ae. aegypti and other species (e.g., Stein et al. 2002, Zapata et al. 2002) but there are no studies testing the occurrence of interspecific competition in field or laboratory conditions. Field experiments using ovitraps in temperate localities suggested that the presence of conspecific eggs and/or immatures did not affect oviposition activity (Campos \& Maciá 1996, Almirón et al. 1999). Recently, Maciá (2006) measured Ae. aegypti fitness components (i.e., pupal weight, total biomass, survivorship, development time and female fecundity) in relation to larval density and container type. This study suggested that Ae. aegypti populations in temperate Argentina are subjected to intraspecific competition and that its intensity depends on the quality of the container type.

Chemical and biological control - Chemical control methods have been frequently and intensively used in the North of the country during DF outbreaks, although published papers on this issue are scarce. Susceptibility to six concentrations of the larvicide temephos was tested for Ae. aegypti subpopulations from CO, CA and MI by Biber et al. (2006). Their laboratory results suggest the existence of resistance at least in the subpopulation from $\mathrm{CO}$, providing the first evidence of mosquito resistance to temephos in the country. In a cemetery from Buenos Aires city the percentage of Ae. aegypti larval habitats decreased from $18.4 \%$ to $2.2 \%$ with only two applications of temephos during the reproductive season, and to $0.05 \%$ with five applications (Vezzani et al. 2004c). Unfortunately, after five years of interrupting control actions, infestation levels have almost reached earlier values (unpublished observation). Temephos was also used in combination with Bacillus thuringiensis var. israelensis (Bti), the pyrethroid cypermethrin and an educational campaign in a locality of FO, where autochthonous dengue transmission was confirmed (Masuh et al. 2003a). After implementation of the integrated control program, $\mathrm{HI}$ and BI fell from $39 \%$ and 87 to $3 \%$ and 4 , respectively. Fumigant canister of 5\% beta-cypermethrin were tested inside houses of Colonia Delicia (MI), showing excellent adulticide effectiveness and a decrease of $\mathrm{HI}$ and $\mathrm{BI}$ from $51 \%$ and 106 to $23 \%$ and 44 , respectively (Masuh et al. 2003b). Afterwards, a new water-based ultra low volume formulation of cypermethrin evaluated in the laboratory was effective as adulticide and produced less irritation than other insecticides like deltamethrin (Seccacini et al. 2006).

Regarding biological agents, a novel strain of $B$. thuringiensis was recently cloned and characterized, and trials against Ae. aegypti (4th instar larva) suggested higher mosquitocidal activity than that of the reference Bti strain (Berón \& Salerno 2007). Laboratory and field experiments with the copepod Mesocyclops annulatus suggested that this predator is a promising biocontrol agent for Ae. aegypti (Micieli et al. 2002, Marti et al. 2004). However, Achinelly et al. (2003) found that M. annulatus has a high predation activity against another potential control agent, the nematode Strelkovimermis spiculatus, and therefore the interference between both biological agents should be considered in control programs. The 
susceptibility of Ae. aegypti to $S$. spiculatus was higher than $90 \%$ for 1 st and 2 nd instars and decreased toward the 4th instar (Achinelly et al. 2004, Achinelly \& Camino 2005). Laboratory assays with the fungus Leptolegnia chapmanii found $85 \%$ of susceptibility for 4 th instar and $100 \%$ for 1 st - 3rd larvae (López Lastra et al. 2004). Posterior studies determined that this fungus was infectious within a wide range of temperature $\left(10-35^{\circ} \mathrm{C}\right), \mathrm{pH}$ levels (4-10) and $\mathrm{NaCl}$ concentrations (0-7 ppt) that could be found in natural habitats (Pelizza et al. 2007).

Aedes albopictus - Despite Ae. albopictus presence in the Northeast of the country since a decade ago, there is almost no information published about its biological features. Immatures were found inhabiting a small dish, a plough disk and a tin pot in shaded areas of a garden in the locality of San Antonio (Rossi et al. 1999), and in a glass aquarium under vegetation in the Iguazú National Park (Rossi et al. 2006). Another survey found immatures in 33 out of 2,237 water containers examined in $16 \%$ of 161 premises inspected in Eldorado city (Schweigmann et al. 2004). Infested containers were as follow: jars, bins, cans, flasks, casseroles, buckets, cut plastic bottles, tires, a cooking stove, a car battery, a broken drainage pipe and a plastic toy. The authors reported that Ae. albopictus abundance was low compared to Ae. aegypti $(\approx 1: 10)$ and that both species were frequently collected in the same containers.

\section{DISCUSSION AND FUTURE DIRECTIONS}

Argentina suffered several DF outbreaks in the warmest areas during summer. These epidemics took place in localities close to international borders (55 km at most) and corresponded in time and DENV serotypes with outbreaks in the neighboring countries (Brazil, Paraguay and Bolivia). As no year-round transmission was demonstrated and outbreaks had not happened isolated in Argentina, the disease might be considered as epidemic and nonendemic, with the virus entering during the summer from endemic countries. Dengue transmission risk maps for Argentina (Carbajo et al. 2001) and for the world (e.g., Hales et al. 2002, Farrar et al. 2007) predicted the potential area at risk as far as temperate Argentina (BA). Until the present, virus transmission was not demonstrated up to those latitudes, but isolated cases could be expected in the next years due to the high number of imported cases frequently detected. The future dengue situation in Argentina could get worse due to the presence of three DENV serotypes, which increases DHF risk in the North of the country. In addition, the predicted climate change for the next decades increases the chance of dengue expansion (Githeko et al. 2000, Hales et al. 2002); e.g., a rise of $2^{\circ} \mathrm{C}$ during this century would increase up to five times the risk of dengue transmission in South America and new transmission areas would be expected in the Southern part of the continent (Githeko et al. 2000). Although these global scale models provide valuable information, local studies about the effect of climate change in Argentina are pending.

Invasive mosquito species can enhance the transmission of a resident disease and/or introduce a new one in a region (Juliano \& Lounibos 2005). The presence of $A e$. albopictus in Argentina certainly implies a risk to human health due to its potential to act as a bridge vector between rural and urban DF and YF, and also for other arboviruses as West Nile (Gratz 2004). In America, it was never implicated in dengue transmission and a study performed in Brazil (Degallier et al. 2003) suggested that it still cannot be considered an inter-human dengue vector. However, it was found naturally infected with dengue virus in Brazil (Serufo et al. 1993) and in Mexico (Ibañez-Bernal et al. 1997). Concerning other Ae. albopictus potentially transmissible arboviruses, West Nile and Saint Louis encephalitis viruses were recently detected in Argentina (Diaz et al. 2006, Morales et al. 2006). The true epidemiological implications of Ae. albopictus spread on diseases transmission are unknown for Argentina as well as for other South American countries.

A recent global model of the potential geographic range of Ae. albopictus (Benedict et al. 2007) predicted its occurrence as far as Southern BA. Despite of the establishment of Ae. albopictus in Northeastern Argentina ten years ago, its spread toward the temperate areas has not been recorded yet (Rossi et al. 2006). To our knowledge, there are researchers monitoring mosquito populations in certain areas of $\mathrm{MI}, \mathrm{CR}, \mathrm{FO}, \mathrm{JU}, \mathrm{SA}, \mathrm{CH}, \mathrm{CO}$ and BA. Therefore, it might be considered that the spread of Ae. albopictus would be detected. The geographic distribution of this mosquito species in Argentina strongly suggests that it was introduced from Southern states of Brazil. The reasons why Ae. albopictus did not spread toward the South are unclear, particularly considering the recent finding of diapause response in local populations of the southernmost Brazilian states (Lounibos et al. 2003). Besides the main interest in Ae. albopictus as a vector, its presence in the country opens the chance to study the ecological features of this invasive species in its Southern distribution limit, with particular emphasis on interspecific interactions. In Brazil, Ae. albopictus seems to be a superior larval competitor over Ae. aegypti (Braks et al. 2004) as it was also described in the USA (Juliano 1998, Juliano et al. 2004).

The studies performed in Argentina about seasonality, habitat and abundance of Ae. aegypti provide valuable, although preliminary, information to understand or assess spatial and temporal risk of dengue transmission at the local level. The marked seasonal patterns observed for Ae. aegypti in Argentina were similar to those reported in Brazil (e.g., Honório \& Lourenco-de-Oliveira 2001, Favier et al. 2006), but notwithstanding this, immature mosquitoes were collected throughout the year in the later but not in temperate Argentina. In Buenos Aires city, high urbanization degree was associated with lower oviposition activity, apparently contradicting those results obtained in Rio de Janeiro by Braks et al. (2003) and Lima-Camara et al. (2006). However, it should be noted that all the urbanization levels described for Buenos Aires would be classified as urban according to Brazilian studies. Therefore, in order to perform suitable comparative analysis, future studies might try to associate infestation levels to quantitative variables that characterize ur- 
banization degrees. Regarding key containers for vector control, those of wide mouth were identified as the most productive, as was observed elsewhere; for example Maciel de Freitas et al. (2007b) in Rio de Janeiro. However, key container identification based on pupal productivity is a pending issue in almost all Argentinean provinces. Vector abundances estimated through traditional indexes were similar or even higher in Argentina than in Brazil (Luz et al. 2003, Favier et al. 2006, Maciel de Freitas et al. 2007b), but this comparison is doubtful due to the low number of premises inspected in many Argentinean studies. Other main gap in Argentina is the solely use of traditional indices instead of pupal/demographic survey to assess the actual risk of dengue transmission (Focks \& Alexander 2006). Also, local missing studies essential for risk assessment are vector survivorship and extrinsic incubation period (Luz et al. 2003) and those dealing with flight range and dispersal pattern (e.g., Honório et al. 2003, Maciel de Freitas et al. 2007a).

Biological and chemical control studies showed that some efficient tools to reduce vector populations are available in Argentina, but control agents were mainly tested in laboratory conditions and further assays over field populations of Aedes spp. are needed. The level of temephos resistance recently detected was similar to that of Southern Bolivia (Biber et al. 2006) and much lower than the values recorded in Brazil (Braga et al. 2004, Macoris et al. 2007) and the Caribbean countries (Rawlings 1999). Considering that the insecticide pressure has been more intense in Brazil (Macoris et al. 2007) and the Caribbean, mosquito resistance to temephos in Argentina will probably increase in the future. A resistance monitoring program is needed in order to improve mosquito control interventions as, for example, was done in some localities of Brazil with the replacement of temephos by Bacillus spp. (Regis et al. 2000, Braga et al. 2004).

In brief, although a lot of work was done in Argentina during the last two decades, the present work evidences that some main issues are still pending or poorly developed. Finally, about $70 \%$ of the published investigations were carried out in areas where dengue outbreaks have never happened. Scientific research should be increased in the North of the country, where DF epidemics have occurred during the last decade and DHF is currently an actual risk. We recognize that many control and preventive actions performed mainly by health services were also made and that these are not usually published. In this sense, the cooperation between health agencies and scientific researchers should be enforced with the aim to increase the available information on dengue and mosquito vectors in Argentina.

\section{ACKNOWLEDGEMENT}

To Pablo Orellano from the National Ministry of Health for providing information about dengue in Argentina and for suggestions concerning revision of the manuscript.

\section{REFERENCES}

Achinelly MF, Camino NB 2005. Evaluation of the mosquitoes Aedes aegypti and Culex pipiens (Diptera: Culicidae) as alternative hosts for laboratory mass-rearing of Strelkovimermis spiculatus (Nematoda: Mermithidae). Nematology 7: 281-284.
Achinelly MF, Micieli MV, García JJ 2003. Pre-parasitic juveniles of Strelkovimermis spiculatus Poinar \& Camino, 1986 (Nematoda: Mermithidae) predated upon by freshwater copepods (Crustacea: Copepoda). Nematology 5: 885-888.

Achinelly MF, Micieli MV, Marti GA, García JJ 2004. Susceptibility of neotropical mosquito larvae (Diptera: Culicidae) and nontarget aquatic organisms to the entomopathogenic nematode Strelkovimermis spiculatus Poinar \& Camino 1986 (Nemata: Mermithidae). Nematology 6: 299-302.

Almirón WR, Asis R 2003. Indices de abundancia de larvas y pupas de Aedes aegypti (Diptera: Culicidae) en la ciudad de Córdoba. Rev Fac Ciencias Méd 60: 37-41.

Almirón WR, Ludueña Almeida F 1998. Aedes aegypti (Diptera: Culicidae) en Córdoba, Argentina. Rev Soc Entomol Argent 57: 27-28.

Almirón WR, Ludueña Almeida FF, Domínguez MC 1999. Preferencia de Aedes aegypti (Diptera: Culicidae) por sitios para oviposición con diferentes niveles de precolonización y exposición al sol. Rev Soc Entomol Argent 58: 159-164.

Avilés G, Cecchini R, Harrington ME, Cichero J, Asis R, Rios C 1997. Aedes aegypti in Córdoba province, Argentina. J Am Mosq Control Assoc 13: 255-258.

Avilés G, Meissner J, Mantovani R, Jeor S 2003a. Complete coding sequences of dengue-1 viruses from Paraguay and Argentina. $\mathrm{Vi}$ rus Res 98: 75-82.

Avilés G, Paz MV, Rangeon G, Ranaivoarisoa MY, Verzeri N, Roginski S, Baroni P, Enria D 2003b. Laboratory Surveillance of Dengue in Argentina, 1995-2001. Emerg Infec Dis 9: 738-742.

Avilés G, Rangeon G, Vorndam V, Briones A, Baroni P, Enria D, Sabattini MS 1999. Dengue reemergence in Argentina. Emerg Infec Dis 5: 575-578.

Badano EI, Regidor HA 2002. Selección de hábitat de oviposición en Aedes aegypti (Diptera: Culicidae) mediante estímulos físicos. Ecol Aust 12: 129-134.

Barrero PR, Mistchenko AS 2004. Complete genome sequencing of dengue virus type 1 isolated in Buenos Aires, Argentina. Virus Res 101: 135-145.

Bejarán RA, de Garín AB, Carbajo AE, Curto S, Schweigmann N 2000. Control atmosférico del estado adulto de Aedes aegypti y la posibilidad de transmisión del virus del dengue en Argentina. Meteorológica 25: 57-66.

Bejarano JFR 1979. Estudio sobre la fiebre amarilla selvática en la República Argentina, Subsecretaria de Medicina Sanitaria, República Argentina, 38 pp.

BEN 2001. Boletín Epidemiológico Nacional 2000-2001. Ministerio de Salud, República Argentina, 45 pp.

BEN 2003. Boletín Epidemiológico Nacional 2003. Ministerio de Salud y Ambiente de la Nación, República Argentina, 104 pp.

Benedict MQ, Levine RS, Hawley WA, Lounibos LP 2007. Spread of the tiger: global risk of invasion by the mosquito Aedes albopictus. Vect Born Zoon Dis 7: 76-85.

Berón CM, Salerno GL 2007. Cloning and characterization of a novel crystal protein from a native Bacillus thuringiensis isolate highly active against Aedes aegypti. Curr Microbiol 54: 271-276.

Biber PA, Dueñas JR, Ludueña Almeida FF, Gardenal CN, Almirón WR 2006. Laboratory evaluation of susceptibility of natural subpopulations of Aedes aegypti larvae to temephos. J Am Mosq Control Assoc 22: 408-411.

Borda CE, Rea MF, Rosa JR, Mosqueda LA, Sario H 1999. Vector de la fiebre amarilla urbana y el dengue en la Ciudad de Corrientes - Argentina. Comunicaciones Científicas y Tecnológicas de las 
Universidad Nacional del Nordeste, Corrientes. Available from: http://www.unne.edu.ar/cyt/cyt2000.htm.

Braga IA, Lima JBP, Soares SS, Valle D 2004. Aedes aegypti resistance to temephos during 2001 in several municipalities in the states of Rio de Janeiro, Sergipe, and Alagoas, Brazil. Mem Inst Oswaldo Cruz 99: 199-203.

Braks MAH, Honório NA, Lounibos PL, Lourenço-de-Oliveira R, Juliano SA 2004. Interspecific competition between two invasive species of container mosquitoes, Aedes aegypti and Aedes albopictus (Diptera: Culicidae), in Brazil. Annals Entomol Soc Am 97: 130-139.

Braks MAH, Honório NA, Lourenço-de-Oliveira R, Juliano SA, Lounibos LP 2003. Convergent habitat segregation of Aedes aegypti and Aedes albopictus (Diptera: Culicidae) in Southeastern Brazil and Florida. J Med Entomol 40: 785-794.

Campos RE 1993. Presencia de Aedes (Stegomyia) aegypti L. (Diptera: Culicidae) en la localidad de Quilmes (Buenos Aires, Argentina). Rev Soc Entomol Argent 52: 36.

Campos RE, Macia A 1996. Observaciones biológicas de una población natural de Aedes aegypti (Diptera: Culicidae) en la Provincia de Buenos Aires, Argentina. Rev Soc Entomol Argent 55: 67-72.

Carbajo AE, Curto SI, Schweigmann N 2006. Spatial distribution pattern of oviposition in the mosquito Aedes aegypti in relation to urbanization in Buenos Aires: southern fringe bionomics of an introduced vector. Med Vet Entomol 20: 209-218.

Carbajo AE, Gómez SM, Curto SI, Schweigmann N 2004. Variación espacio-temporal del riesgo de transmisión de dengue en la Ciudad de Buenos Aires. Medicina (B Aires) 64: 231-234.

Carbajo AE, Schweigmann N, Curto SI, de Garin A, Bejarán R 2001. Dengue transmission risk maps of Argentina. Trop Med Int Health 6: 170-183.

Carcavallo RU, Martínez A 1968. Fiebre amarilla, vectores y cadena epidemiológica. In RU Carcavallo, A Martínez, Comunicaciones Científicas - Entomoepidemiología de la República Argentina, n. 13, Tomo I, Investigaciones Científicas de las Fuerzas Armadas Argentinas, Argentina, p. 105-144.

Curto SI, Boffi R, Carbajo AE, Plastina R, Schweigmann N 2002. Reinfestación del territorio argentino por Aedes aegypti. Distribución geográfica (1994-1999). In OD Salomón, Actualizaciones en Artropodología Sanitaria Argentina, Fundación Mundo Sano, Buenos Aires, p. 127-137.

de Garín A, Bejarán RA, Carbajo AE, Casas SI, Schweigmann N 2000. Atmospheric control of Aedes aegypti populations in Buenos Aires (Argentina) and its variability. Int $J$ Biometeorol 44: 148-156.

de Garín A, Bejarán RA, Schweigmann N 2002. Eventos El Niño y La Niña y su relación con la abundancia potencial del vector de dengue en la Argentina. In OD Salomón, Actualizaciones en Artropodología Sanitaria Argentina, Fundación Mundo Sano, Buenos Aires, p. 139-147.

de Sousa GB, Avilés G, Gardenal CN 2000. Allozymic polymorphism in Aedes aegypti populations from Argentina. J Am Mosq Control Assoc 16: 206-209.

de Sousa GB, Blanco A, Gardenal CN 2001. Genetic relationships among Aedes aegypti (Diptera: Culicidae) populations from Argentina using random amplified polymorphic DNA polymerase chain reaction markers. J Med Entomol 38: 371-375.

Degallier N, Teixeira JMS, Soares SS, Pereira RD, Pinto SCF, Chaib AJM, Vasconcelos PFC, Oliveira E 2003. Aedes albopictus may not be vector of dengue virus in human epidemics in Brazil. Rev Saude Publica 37: 386-387.
Diaz LA, Ré V, Almirón WR, Farías A, Vázquez A, Sanchez-Seco MP, Aguilar J, Spinsanti L, Konigheim B, Visintin A, García J, Morales MA, Tenorio A, Contigiani M 2006. Genotype III Saint Louis Encephalitis virus outbreak, Argentina, 2005. Emerg Infec Dis 12: 1752-1754.

Domínguez C, Lagos S 2001. Presencia de Aedes aegypti (Diptera: Culicidae) en la provincia de Mendoza, Argentina. Rev Soc Entomol Argent 60: 79-80.

Domínguez C, Ludueña Almeida FF, Almirón WR 2000. Dinámica poblacional de Aedes aegypti (Diptera: Culicidae) en Córdoba Capital. Rev Soc Entomol Argent 59: 41-50.

Farrar J, Focks DA, Gubler D, Barrera R, Guzmán MG, Simmons C, Kalayanarooj S, Lum L, McCall PJ, Lloyd L, Horstick O, DayalDrager R, Nathan MB, Kroeger A 2007. Towards a global dengue research agenda. Trop Med Int Health 12: 695-699.

Favier C, Degallier N, Vilarinhos PTR, Laurentino de Carvalho MS, Yoshizawa MAC, Knox MB 2006. Effects of climate and different management strategies on Aedes aegypti breeding sites: a longitudinal survey in Brasilia (DF, Brazil). Trop Med Int Health 11: 1104-1118.

Focks DA, Alexander N 2006. Multicountry study of Aedes aegypti pupal productivity survey methodology. Findings and recommendations, Special Programme for Research and Training in Tropical Diseases, TDR/IRM/DEN/06.1, Geneva. Available from: http://www.who.int/tdr/publications/publications/pdf/aedes_aegypti.pdf.

García JJ, Micieli MV, Achinelly MF, Marti GA 2002. Establecimiento de una población de Aedes aegypti L. en La Plata, Argentina. In OD Salomón, Actualizaciones en Artropodología Sanitaria Argentina, Fundación Mundo Sano, Buenos Aires, pp. 149-153.

Gaudino NM 1916. El dengue: Algunas consideraciones sobre la epidemia de Entre Ríos de 1916. Rev Sanidad Mil 15: 617-627.

Gianella A, Pirard M, Holzman A, Boelaert M, Fernández-Ortíz F, Peredo C, Pelegrino JL, Van der Stuyft P 1998. Epidemic outbreak of Dengue virus 2/subgroup Jamaica in Bolivia. Salud Púb Mex 40: 469-473.

Githeko AK, Lindsay SW, Confalonieri UE, Patz JA 2000. Climate change and vector-borne diseases: a regional analysis. Bull World Health Organ 78: 1136-1147.

Gorodner JO, Seijo A, Payes MF, Robles B, Basualdo C, Pacce M, Botinelli O, Alonso JM, Boffi R 2000. Circulación de virus dengue en el nordeste argentino. Comunicaciones Científicas y Tecnológicas de las Universidad Nacional del Nordeste, Corrientes. Available from: http://www.unne.edu.ar/cyt/2000/cyt.htm.

Gratz NG 2004. Critical review of the vector status of Aedes albopictus. Med Vet Entomol 18: 215-227.

Hales S, Wet N, Maindonald J, Woodward A 2002. Potential effect of population and climate changes on global distribution of dengue fever: an empirical model. Lancet 360: 830-834.

Hawley WA 1988. The biology of Aedes albopictus. J Am Mosq Control Assoc 4: 1-39.

Honório NA, Cabello PH, Codeço CT, Lourenço-de-Oliveira R 2006. Preliminary data on the performance of Aedes aegypti and Aedes albopictus immatures developing in water-filled tires in Rio de Janeiro. Mem Inst Oswaldo Cruz 101: 225-228.

Honório NA, Lourenço-de-Oliveira R 2001. Frequency of Aedes aegypti and Aedes albopictus larvae and pupae in traps, Brazil. Rev Saude Pública 35: 385-391.

Honório NA, Silva WC, Leite PJ, Goncalves JM, Lounibos LP, Lourenço-de-Oliveira R 2003. Dispersal of Aedes aegypti and Aedes 
albopictus (Diptera: Culicidae) in an urban endemic dengue area in the State of Rio de Janeiro, Brazil. Mem Inst Oswaldo Cruz 98: 191-198.

Ibáñez-Bernal S, Briseño B, Mutebi JP, Argot E, Rodríguez A, Martínez-Campos C, Paz R, de la Fuente-San Román P, Tapia-Conyer R, Flisser A 1997. First record in America of Aedes albopictus naturally infected with dengue virus during an outbreak of Reynosa, Mexico in 1995. Med Vet Entomol 11: 305-309.

Juliano SA 1998. Species introduction and replacement among mosquitoes: interspecific resource competition or apparent competition? Ecology 79: 255-268.

Juliano SA, Lounibos LP 2005. Ecology of invasive mosquitoes: effects on resident species and on human health. Ecol Lett 8: 558-574.

Juliano SA, Lounibos LP, O'Meara GF 2004. A field test for competitive effects of Aedes albopictus on A. aegypti in South Florida: differences between sites of coexistence and exclusion? Oecologia 139: 583-593.

Junín B, Grandinetti H, Marconi JM, Carcavallo RU 1995. Vigilancia de Aedes aegypti (L) en la ciudad de Buenos Aires (Argentina). Entomol Vect 2: 71-75.

Lima-Camara TN, Honório NA, Lourenço-de-Oliveira R 2006. Frequency and spatial distribution of Aedes aegypti and Aedes albopictus (Diptera, Culicidae) in Rio de Janeiro, Brazil. Cad Saude Publica 22: 2079-2084.

López Lastra CC, Scorsetti AC, Marti GA, García JJ 2004. Host range and specificity of an Argentinean isolate of the aquatic fungus Leptolegnia chapmanii (Oomycetes: Saprolegniales), a pathogen of mosquito larvae (Diptera: Culicidae). Mycopathologia 158: 311-315.

Lounibos LP 2002. Invasions by insect vectors of human disease. Annu Rev Entomol 47: 233-266.

Lounibos LP, Escher RL, Lourenço-de-Oliveira R 2003. Asymmetric evolution of photoperiodic diapause in temperate and tropical invasive populations of Aedes albopictus (Diptera: Culicidae). Ann Entomol Soc Am 96: 512-518.

Luz PM, Codeço CT, Massad E, Struchiner CJ 2003. Uncertainties regarding dengue modeling in Rio de Janeiro, Brazil. Mem Inst Oswaldo Cruz 98: 871-878.

Maciá A 2006. Differences in performance of Aedes aegypti larvae raised at different densities in tires and ovitraps under field conditions in Argentina. $J$ Vector Ecol 31: 371-377.

Maciel-de-Freitas R, Codeço CT, Lourenço de Oliveira R 2007a. Body size-associated survival and dispersal rates of Aedes aegypti in Rio de Janeiro. Med Vet Entomol 21: 284-292.

Maciel-de-Freitas R, Marques WA, Peres RC, Cunha SP, Lourenço de Oliveira R 2007b. Variation in Aedes aegypti (Diptera: Culicidae) container productivity in a slum and a suburban district of Rio de Janeiro during dry and wet seasons. Mem Inst Oswaldo Cruz 102: 489-496.

Macoris MLG, Andrighetti, MTM, Otrera VCG, Carvalho RL, Caldas AL Jr, Brogdon WG1 2007. Association of insecticide use and alteration on Aedes aegypti susceptibility status. Mem Inst Oswaldo Cruz 102: 895-900.

Marques GRAM, Santos RLC, Forattini OP 2001. Aedes albopictus in bromeliads of anthropic environment in São Paulo State, Brazil. Rev Saude Publica 35: 243-248.

Marti GA, Micieli MV, Scorsetti AC, Liljesthröm G 2004. Evaluation of Mesocyclops annulatus (Copepoda: Cyclopoidea) as a control agent of Aedes aegypti (Diptera: Culicidae) in Argentina. Mem Inst Oswaldo Cruz 99: 535-540.

Masuh H, Coto H, Licastro S, Zerba E 2003a. Control de Aedes ae- gypti (L.) en Clorinda: un modelo para areas urbanas. Entomol Vect 10: 485-494.

Masuh H, Licastro S, Lopez PA, Vega C, Zerba E 2003b. Field evaluation of smoke-generating formulation containing beta-cypermethrin against the dengue vector in Argentina. J Am Mosq Control Assoc 19: 53-57.

Micieli MV, Campos RE 2003. Oviposition activity and seasonal pattern of a population of Aedes (Stegomyia) aegypti (L.) (Diptera: Culicidae) in Subtropical Argentina. Mem Inst Oswaldo Cruz 98: 659-663.

Micieli MV, García JJ, Achinelly MF, Martí GA 2006. Dinámica poblacional de los estadios inmaduros del vector del dengue $A e$ des aegypti (Diptera: Culicidae): un estudio longitudinal (19962000). Rev Biol Trop 54: 979-983.

Micieli MV, Marti G, García JJ 2002. Laboratory evaluation of Mesocyclops annulatus (Wierzejski, 1892) (Copepoda: Cyclopidea) as a predator of container-breeding mosquitoes in Argentina. Mem Inst Oswaldo Cruz 97: 835-838.

Monath TP 2001. Yellow Fever. In MW Service, The Encyclopedia of Arthropod-transmitted Infections of Man and Domesticated Animals, CABI Publishing, Wallingford, p. 571-577.

Morales MA, Barrandeguy M, Fabbri C, Garcia JB, Vissani A, Trono K, Gutierrez G, Pigretti S, Menchaca H, Garrido N, Taylor N, Fernandez F, Levis S, Enría D 2006. West Nile virus isolation from equines in Argentina, 2006. Emerg Infec Dis 12: 1559-1561.

MSC - Ministerio de Salud de Chile 2007. Situación epidemiológica dengue en Isla de Pascua, Chile insular, 18/04/2007. Departamento de Epidemiología, Ministerio de Salud, Chile. Available from: http://epi.minsal.cl/epi/html/bolets/reportes/Dengue/InfSituacDENGUEchile.pdf.

O'Meara GF, Evans LF, Gettman AD, Cuda JP 1995. Spread of Aedes albopictus and decline of Ae. aegypti (Diptera: Culicidae) in Florida. J Med Entomol 32: 554-562.

Otero M, Solari HG, Schweigmann N 2006. A stochastic population dynamics model for Aedes aegypti: formulation and application to a city with temperate climate. Bull Math Biol 68: 1945-1974.

PAHO - Pan-American Health Organization 1994. Dengue and Dengue Hemorrhagic Fever in the Americas: Guidelines for Prevention and Control, PAHO Scientific Publication n. 548, Washington, 98 pp.

PAHO - Pan-American Health Organization 2007. Number of reported cases of dengue \& dengue hemorrhagic fever, region of the Americas by country and subregion, PAHO, Washington. Available from: http://www.paho.org/Spanish/AD/DPC/CD/dengue.htm

Passos RA, Marques GRAM, Voltolini JC, Condino MLF 2003. Dominance of Aedes aegypti over Aedes albopictus in the southeastern coast of Brazil. Rev Saude Publica 37: 729-734.

Pedroni E 2001. Evaluación de las intervenciones de prevención y control de la fiebre amarilla en áreas de riesgo de las provincias de Corrientes y Misiones, Ministerio de Salud de la Nación, Technical report, Argentina, 9 pp.

Pelizza SA, López Lastra CC, Becnel JJ, Bisaro V, García JJ 2007. Effects of temperature, $\mathrm{pH}$ and salinity on the infection of Leptolegnia chapmanii Seymour (Peronosporomycetes) in mosquito larvae. J Invertebr Pathol 96: 133-137.

Rai K 1991. Aedes albopictus in the Americas. Annu Rev Entomol 36: 459-484.

Rawlins SC 1999. Spatial distribution of resistance to insecticides in Caribbean populations of the dengue vector, Aedes aegypti and it's significance. Proceedings of the CAREC/PAHO, Sub-Regional Dengue Meeting, Port of Spain Trinidad, p. 11-17. 
Regis L, Silva SB, Melo-Santos MA 2000. The use of bacterial larvicides in mosquito and black fly control programmes in Brazil. Mem Inst Oswaldo Cruz 95: 207-210.

Rossi GC, Lestani EA, D'Oria JM 2006. Nuevos registros y distribución de mosquitos de la Argentina (Diptera: Culicidae). Rev Soc Entomol Argent 65: 51-56.

Rossi GC, Martínez M 2003. Mosquitos (Diptera: Culicidae) del Uruguay. Entomol Vect 10: 469-478.

Rossi GC, Pascual NT, Krsticevic FJ 1999. First record of Aedes albopictus (Skuse) from Argentina. J Am Mosq Control Assoc 15: 422.

Rotela C, Fouque F, Lamfri M, Sabatier P, Introini V, Zaidenberg M, Scavuzzo C 2007. Space-time analysis of the dengue spreading dynamics in the 2004 Tartagal outbreak, Northern Argentina. Acta Trop 103: 1-13.

Salvatella R 1997. Aedes aegypti (Diptera, Culicidae). Notificación de su presencia en Uruguay. Rev Méd Urug 13: 118-121.

Salvatella R, Rosa R 2003. Culicidos y salud humana en el Uruguay. Entomol Vect 10: 431-436.

San Martín JL, Brathwaite-Dick O 2007. La estrategia de gestión integrada para la prevención y el control del dengue en la región de las Américas. Pan Am J Public Health 21: 55-63.

Schatzmayr HG 2000. Dengue situation in Brazil by year 2000. Mem Inst Oswaldo Cruz 95: 179-181.

Schatzmayr HG, Nogueira RM, Travassos da Rosa AP 1986. An outbreak of dengue virus at Rio de Janeiro. Mem Inst Oswaldo Cruz 81: 245-246.

Schweigmann N, Orellano P, Kuruc J, Vera MT, Vezzani D, Méndez A 2002. Distribución y abundancia de Aedes aegypti (Diptera: Culicidae) en la ciudad de Buenos Aires. In OD Salomón, Actualizaciones en Artropodología Sanitaria Argentina, Fundación Mundo Sano, Buenos Aires, p. 155-160.

Schweigmann N, Vezzani D, Orellano P, Kuruc J, Boffi R 2004. Aedes albopictus in an area of Misiones, Argentina. Rev Saude Publica 38: 136-138.

Schweigmann N, Vezzani D, Vera T, Gómez S, Fernández Campón F, Cevasco C, Freire MG, Kuruc J, Ackermann G, Carbajo A, Bruzzone O, Boffi R, Abramo Orrego L 1997. Infestación domiciliaria por formas inmaduras de Aedes (Stegomyia) aegypti L. en un foco del Partido de San Martín, Provincia de Buenos Aires, Argentina - Otoño de 1996. Entomol Vect 4: 185-190.

Seccacini E, Masuh H, Licastro SA, Zerba E 2006. Laboratory and scaled up evaluation of cis-permethrin applied as a new ultra low volume formulation against Aedes aegypti (Diptera: Culicidae). Acta Trop 97: 1-4.

Seijo A, Curcio D, Avilés G, Cernigoi B, Deodato B, Lloveras S 2000. Imported dengue in Buenos Aires, Argentina. Emerg Infec Dis 6: 655-656.

Serufo JC, Montes de Oca H, Tavares VA, Souza AM, Rosa RV, Jamal MC, Lemos JR, Oliveira MA, Noguiera RMR, Schatzmayr HG 1993. Isolation of dengue virus type 1 from larvae of Aedes albopictus in Campos Altos City, State of Minas Gerais, Brazil. Mem Inst Oswaldo Cruz 88: 503-504.
Stein M, Oria GI 2002. Identificación de criaderos de Aedes aegypti (Diptera: Culicidae) y cálculo de índices de infestación en la provincia del Chaco. In OD Salomón, Actualizaciones en Artropodología Sanitaria Argentina, Fundación Mundo Sano, Buenos Aires, p. 161-166.

Stein M, Oria GI, Almirón WR 2002. Main breeding-containers for Aedes aegypti and associated culicids, Argentina. Rev Saude Publica 36: 627-30.

Stein M, Oria GI, Almirón WR, Willener JA 2005. Seasonal fluctuation of Aedes aegypti in Chaco Province, Argentina. Rev Saude Publica 39: 559-564.

Van der Stuyft P, Gianella A, Pirard M, Cespedes J, Lora J, Peredo C, Pelegrino JL, Vorndam V, Boelaert M 1999. Urbanisation of yellow fever in Santa Cruz, Bolivia. Lancet 353: 1558-1562.

Vezzani D, Rubio A, Velázquez SM, Schweigmann N, Wiegand T 2005. Detailed assessment of microhabitat suitability for Aedes aegypti (Diptera: Culicidae) in Buenos Aires, Argentina. Acta Trop 95: 123-131.

Vezzani D, Schweigmann N 2002. Suitability of containers from different sources as breeding sites of Aedes aegypti (L.) in a cemetery of Buenos Aires City, Argentina. Mem Inst Oswaldo Cruz 97: 789-792.

Vezzani D, Velázquez SM, Schweigmann N 2004a. Seasonal pattern of abundance of Aedes aegypti (Diptera: Culicidae) in Buenos Aires City, Argentina. Mem Inst Oswaldo Cruz 99: 351-356.

Vezzani D, Velázquez SM, Schweigmann N 2004b. Containers of different capacity as breeding sites of Aedes aegypti (Diptera: $\mathrm{Cu}-$ licidae) in the cemeteries of Buenos Aires, Argentina. Entomol Vect 11: 305-316.

Vezzani D, Velázquez SM, Schweigmann N 2004c. Control of Aedes aegypti with temephos in a Buenos Aires cemetery, Argentina. Rev Saude Publica 38: 378-340.

Vezzani D, Velázquez SM, Soto S, Schweigmann N 2001. Environmental characteristics of the cemeteries of Buenos Aires City (Argentina) and infestation levels of Aedes aegypti (Diptera: $\mathrm{Cu}-$ licidae). Mem Inst Oswaldo Cruz 96: 467-471.

WER 2000. Yellow fever, 1998-1999. Weekly Epidemiol Rec 75: 321-328.

WER 2005. The yellow fever situation in Africa and South America in 2004. Weekly Epidemiol Rec 80: 250-256.

WER 2006. Yellow fever situation in Africa and South America, 2005. Weekly Epidemiol Rec 81: 317-324.

WHO - World Health Organization 2000. Strengthening implementation of the global strategy for dengue fever/dengue hemorrhagic fever prevention and control: report of the informal consultation; 18-20 October 1999; World Health Organization Headquarter, Geneva. Available from: http://whqlibdoc.who.int/hq/2000/ WHO_CDS_(DEN)_IC_2000.1.pdf.

Zapata L, Mari E, Stein M, Gorodner JO 2002. Criaderos de Aedes aegypti y la culicidofauna asociada (Díptera: Culicidae) en la Ciudad de Corrientes. Comunicaciones Científicas y Tecnológicas de las Universidad Nacional del Nordeste, Corrientes. Available from: hppt://www.unne.edu.ar/cyt/2002/06-Biologicas/B-036.pdf. 